\title{
A critical review of postfeminist sensibility
}

Sarah Riley

Aberystwyth University

Adrienne Evans

Coventry University

Sinikka Elliott

University of British Columbia

Carla Rice

University of Guelph

Jeanne Marecek

Swarthmore College

This is the peer reviewed version of the following article: Riley, S., Evans, A., Elliott, S., Rice, C., \& Marecek, J. (2017). A critical review of postfeminist sensibility. Social and Personality Psychology Compass, 11(12), e12367, which has been published in final form at https://doi.org/10.1111/spc3.12367. This article may be used for non-commercial purposes in accordance with Wiley Terms and Conditions for Use of Self-Archived Versions.

\section{Recommended citation:}

Riley, S., Evans, A., Elliott, S., Rice, C., \& Marecek, J. (2017). A critical review of postfeminist sensibility. Social and Personality Psychology Compass, 11(12), e12367. https://doi.org/10.1111/spc3.12367 


\section{A critical review of postfeminist sensibility}

Sarah Riley, Adrienne Evans, Sinikka Elliott, Carla Rice, Jeanne Marecek

\section{Abstract}

This paper critically reviews how feminist academic psychologists, social scientists, and media scholars have developed Rosalind Gill's generative construct "postfeminist sensibility." We describe the key themes of postfeminist sensibility, a noncoherent set of ideas about femininity, embodiment, and empowerment circulating across a range of media. Ideas that inform women's sense of self, making postfeminist sensibility an important object for psychological study. We then consider research that drew on postfeminist sensibility, focusing on new sexual subjectivities, which developed analysis of agency, empowerment, and the possibilities and limitations in taking up new subjectivities associated with postfeminism, as well as who could take up these subjectivities. We show how such work identified complexities and contradictions in postfeminist sensibility and offer suggestions for how this work might be further developed, particularly by intersectionality-informed research. In the final section, we address contemporary debates surrounding postfeminism. We consider challenges and counterarguments to postfeminist sensibility as a useful term for describing contemporary patterns of sense-making on gender, making the case for continuing research on postfeminist sensibility in the areas of digital cultures, a transformative imperative that includes the mind as well as the body, transnational postfeminism, and new forms of feminist activism. We conclude that such work would benefit from considering the 
ways that different technologies mediate the ideas and practices associated with postfeminist sensibility.

\section{INTRODUCTION}

In this paper, we provide an overview of how feminist academic psychologists, social scientists, and media scholars have developed Gill's (2007a, 2007c) generative construct "postfeminist sensibility." We document the development of the construct, asking: how has the term been used and to what effect? What kind of research endeavours has been stimulated? And what directions for future research do we envisage?

In engaging with these questions, we approach postfeminist sensibility as a cultural phenomenon (a set of ideas/representations of women circulating in media) that has itself become an object of study, as well as a lens (a sense-making framework or an analytic tool) for recognising and analysing that object of study. We advance understandings of postfeminist sensibility by first summarising the key elements of postfeminist sensibility as outlined in Gill's (2007a, 2007c) work on patterns in the representation of women in contemporary media. We then consider research that draws on postfeminist sensibility to make sense of a range of contemporary gender issues. Given the abundance of research, we focus on "the sexualisation of culture," which is a particularly rich field for investigation. In examining this research, we show how attending to postfeminist sensibility has enabled researchers to describe and analyse "new femininities," that is, emerging forms of idealised femininity. We also detail how sexualisation research paved the way for subsequent researchers to provide valuable insights into a range of contemporary gender issues, in intersection with class, racialised identities, 
and sexuality. In the final section, we address contemporary debates surrounding postfeminism. We consider challenges and counterarguments to postfeminist sensibility as a useful term for describing contemporary patterns of sense-making on gender, making the case for continuing research on postfeminist sensibility.

Before we discuss postfeminist sensibility, we note that there have been several uses of the term postfeminism. Postfeminism can describe a historical period in feminist thought and action as well as an epistemological break or a backlash against certain feminist ideas and politics (Gill, 2007c). In the historical break narrative, different kinds of feminism are understood as having distinct historical periods, with firstwave feminism associated with civil politics including suffrage and access to education, starting in the 18th century and ending mid-20th century. Second-wave feminism followed, particularly strong in the 1960-1980s; its focus was on gender equality (e.g., equal pay) and interpersonal politics, such as sexual agency and objectification. Second-wave feminism was then replaced by third-wave feminism or postfeminism, which developed a gender politics relevant for a context in which women's cultural and economic enfranchisement was accepted, and where, for example, women could enjoy participating in traditionally feminine beauty practices free of their patriarchal past associations (see Stainton Rogers \& Stainton Rogers, 2001, for a critical historical account, including the argument that all these forms of feminism continue to this day).

In contrast, when used to describe an epistemological break, postfeminism is associated with wider antifoundationalist movements that rejected first- and second-wave feminist theorising for its totalising 
narrative. For example, some theorists used poststructuralist arguments to show how the idea of a unified category of "woman" was a myth (Flax, 1987), though not all those who have called into question "woman" as the unitary subject of feminism have adopted the term "postfeminism" (see Butler, 1990).

Postfeminism has also been used to describe a "backlash" to feminism, an account particularly evident in U.S. media, in which the gains of feminism, such as women's participation in employment, education, or agentic sexuality, are understood as the sources of cultural problems and women's unhappiness or lack of fulfilment (Douglas, 2010).

Important contributions to theorising gender relations were made by researchers upholding these different accounts of postfeminism. But these accounts often employed an overly simplified linear narrative of feminism to postfeminism, with earlier first- and second-wave feminism leading to either progressive (third wave) or regressive (backlash) postfeminism. Such linear accounts failed to recognise the way these "historic" forms of feminism continued to be influential in both contemporary media representations of women and feminist academic analysis of media and gender relations (Hemmings, 2011). All three ways of construing postfeminism also failed to account for the developing complexity of media content. For example, the critique of the backlash discourse overlooked the way popular media texts made use of feminist rhetoric in strategic ways, such as Virginia Slims advertising smoking to women as a way to stay thin, while connecting thinness to independence and empowerment. In contrast, as we argue below, "postfeminist sensibility" offered a way of conceptualising 
postfeminism as a form of media culture that engaged in complex and often contradictory ways with a range of feminist ideas.

\section{INTRODUCING POSTFEMINIST SENSIBILITY}

Gill proposed the term "postfeminist sensibility" to articulate the way popular media culture including "films, television shows, adverts and other media products" (2007a, p. 148) and addressed women as self-made, savvy, empowered consumers. In addressing women this way, postfeminist media culture intertwined second-wave feminist values with the objects of their critique. For example, second-wave feminist values of female autonomy and empowerment were used to construct women's participation in cosmetic surgery as a personal choice. This was despite second-wave feminists associating cosmetic surgery with women's lack of power within a patriarchal society that located women's value in their sexual attractiveness for men. ${ }^{1}$

Considering how postfeminist media culture intertwined feminist values of gender equality with practices previously critiqued by feminists, Gill conceptualised postfeminist sensibility as involving a set of interrelated themes. These themes were as follows: a shift from sexual objectification to sexual subjectification, where women's participation in apparently sexually objectifying practices was understood as the outcome of an agentic,

\footnotetext{
${ }^{1}$ Also see the work of McRobbie (2004, 2009), who argued that postfeminism was "doubly entangled" with feminism, since a postfeminist media address drew on feminist discourses of empowerment and agency while constructing feminism as redundant, either because women were understood as participating equally in public life (thus the "battle" was won) or because the vehicle to expressing politics was now through consumption. For McRobbie, postfeminism thus both drew on and refuted feminism, consigning feminism to "a retirement home in an unfashionable rundown holiday resort" (2004, p. 512), while women who identified as feminist risked unintelligibility within the symbolic realm of postfeminism.
} 
knowing sexuality; femininity as a bodily property produced through practices that required self-surveillance and appearance related bodywork, making the body the locus of women's success and identity; a "make-over paradigm" that reframed consumption and appearance work as empowering and pleasurable through a celebration of its transformative possibilities towards self-actualisation, liberation, and a "better you"; and a reaffirmation of gender difference and biological essentialism that positioned traditional feminine concerns and pleasures around appearance and consumption as natural choices of contemporary women. Combined, these original themes of postfeminist sensibility encouraged women to consider themselves free, "choiceful," and empowered while constraining their choices towards work on the body, often through the use of consumption (Gill, 2007b).

Discussing postfeminist sensibility in 2016, Gill argued "I do not see myself as a 'postfeminist analyst' but as an analyst of postfeminism-a patterned yet contradictory sensibility connected to other dominant ideologies (such as individualism and neoliberalism)" (p. 621). Postfeminist sensibility can therefore be understood as functioning like an ideology, as a set of ideas about gender that can be studied. But in using the term "sensibility," Gill oriented to its affective qualities, although this aspect of postfeminist sensibility is underdeveloped. The term sensibility drew on Raymond Williams's "structure of feeling," itself an undeveloped term, but one used to emphasise the way ideas are produced in interaction with the less tangible, affective, and "feeling" qualities that also make up the experience of a particular cultural moment (Sharma \& Tygstrup, 2015). 
"Sensibility" thus moves us away from thinking about a fixed ideology and towards a more fluid, less coherent, affective set of ideas about femininity. These ideas produce notions of ideal femininity that circulate within a postfeminist media culture, ideas that consumers of such media can draw on to make sense of themselves. Postfeminist sensibility can thus influence subject formation and everyday social relations, offering certain ways of being in the world ("subject positions")) to which women might aspire and for which they might work on themselves so that they can be rendered intelligible through these ideas of ideal femininity. This makes postfeminist sensibility an important object of study for psychologists as well as media and cultural analysts and social scientists such as sociologists.

It is important to highlight how the elements of postfeminist sensibility that Gill described were not coherent, since contradiction is a key aspect of postfeminist sensibility. For example, Gill's (2007a) theme of reaffirming gender difference and biological essentialism can be seen in the celebration of British celebrity chef Nigella Lawson as a "domestic goddess" (Hollows, 2003). Yet domesticity seems to be rejected in the Wonderbra advertisement featuring the slogan "I can't cook. Who cares?" that aligns with Gill's themes of sexual subjectification and the body as a source of success.

Understanding contrasting media representations of women as part of a postfeminist sensibility thus allowed researchers to make connections

\footnotetext{
${ }^{2} \mathrm{~A}$ term used in poststructuralist informed work to describe the kind of people or roles enabled by particular forms of sense making. For example, as we discuss in this paper, postfeminist sensibility provides the sense-making for the subject position of a sexually savvy "up for it woman."
} 
between very different features of a complex media culture. It also allowed researchers to account for patterns in women's sense-making, including the way that second-wave feminist arguments could be mobilised to support practices such feminists had problematised. For example, young women used second-wave feminist arguments around the importance of women being able to express their sexuality to position "glamour" models as empowered by their work (Evans \& Riley, 2013, 2014), even through second-wave feminists had critiqued such work as sexually objectifying.

In summary, the construct of postfeminist sensibility described a series of recurring, but not coherent, themes that circulated across different media, offering new ways of understanding ideal femininity for consumers of such media. A key theme of postfeminist sensibility was the location of women's power and identity in their bodies and sexuality, which led to a significant body of work on emerging sexual subjectivities ${ }^{-3}$ that we describe below.

\section{NEW SEXUAL SUBJECTIVITIES}

By the early 21 st century, a pervasive and heightened public sexuality was evident in a range of media in many Western high-income societies. This occasioned new sexual subjectivities oriented around an actively desiring female sexuality often demonstrated through a hypersexual appearance and an "up for it," sexually knowing, attitude. New sexual subjectivities were linked to postfeminist sensibility since they tied a

\footnotetext{
${ }^{3}$ Subjectivities is a term used in poststructuralist informed work to describe people's sense of self. It is preferred over "identity," to emphasise the way that our sense of self is produced through culturally available discourses.
} 
feminist rhetoric of sexual liberation to a language of individualism, consumerism, and celebration of fitness and beauty-related bodywork. But across academic, media, and government discourse was a concern that young women were being manipulated, "sold" sexual objectification as a form of empowerment, an Orwellian 1984-style disempowerment through empowerment.

In considering these concerns, research on new sexual subjectivities contributed to developments in conceptualising agency and empowerment in women's engagement with postfeminist sensibility (e.g., Duits \& van Zoonen, 2007; Gavey, 2012; Gill, 2007b, 2012; Lamb, 2010a, 2010b; Lamb \& Peterson, 2012; Peterson, 2010; Rice \& Watson, 2016; Tolman, 2012). For example, Evans, Riley, and Shankar (2010) theorised women's uptake of new sexual subjectivities as agentic performances with subversive potential, but which were articulated through historically sexist discourses not of their own making. Others examined notions of sexual freedom in critical ways. For example, Diamond's (2005) media analysis on female celebrity same-sex kissing showed how these kisses affirmed heterosexuality since they were constructed as being done for the pleasure of men.

New sexual subjectivities research troubled the focus on agency as a proxy for liberation or empowerment (e.g., Gavey, 2012; Gill \& Donague, 2013): If empowerment was the language through which postfeminist sensibility was enacted, could it also be used as a feminist analytic? Addressing this question, agency and empowerment themselves became subject to analysis, with the argument that it benefitted advanced capitalism for people to understand the work they did to be "the best you" to 
be acts of liberation and empowerment, rather than coercion towards being a flexible worker and consumer fit for neoliberal ${ }^{4}$ economies (e.g., BayCheng, 2015).

From this perspective, the language of empowerment in postfeminist sensibility directed women's desire towards working on themselves in ways that allowed them to take up new sexual subjectivities as their own. Research then explored the possibilities that were enabled or reduced when women identified as new sexual subjects. For example, using cooperative inquiry as a method to explore the experiences of a group of heterosexual, White British women in their 20s and 30s, Evans and Riley (2014) highlighted both the pleasures of being able to understand oneself as an empowered, sexy, savvy woman and the limitations in taking up these identities, such as needing to belittle other women to create downward comparison or to be constantly seeking out the next thing so as to stay a "sexual connoisseur" in an expanding consumer context.

Considering how women might take up new sexual subjectivities, research identified the way women had to negotiate multiple and contrasting ideas of women's sexuality, since understandings produced from postfeminist media cultures (such as women being empowerment through their sexuality) rubbed up against longstanding moralistic prescriptions of a more passive, "respectable" female sexuality. For

\footnotetext{
${ }^{4}$ Neoliberalism is a term used to describe a set of political-economic ideas that underpin advanced capitalism, which have significant implications for how citizenship is understood. Although there is variation in how neoliberalism develops in different countries, neoliberal citizenship orients around values of self-management and self-enterprise made sense of through discourses of risk, responsibility, choice, and freedom (Ong, 2006). Neoliberalism provides the conditions of possibility for postfeminist sensibility, since an understanding of the self as in need of constant work and transformation, often through the use of consumption, is shared by both neoliberal and postfeminist sensibilities (Gill, 2007; Evans \& Riley, 2014; Riley, Evans \& Robson, forthcoming).
} 
example, in their analysis of interviews, focus groups, and social media with British adolescents in an urban school, Ringrose, Harvey, Gill, and Livingstone (2013) showed how young women understood themselves as sexy when photographing their breasts for sexting purposes but to do so risked "slut shaming."

Similarly, from their interviews with British women drinkers, Griffin, Szmigin, Bengry-Howell, Hackley, and Mistral (2013) argued that workingclass women in particular had to negotiate contradictory constructs of ideal femininity. On the one hand, a visible hypersexy postfeminist femininity was culturally valued by their peers, but on the other, a more subdued workingclass "respectable" sexuality was also required, making the take-up of new sexual subjectivities both prescriptive and risky. Rice's (2014) work with a range of women in Canada also showed the limits for who could understand themselves as knowing sexual agents, since those with disabilities were treated by others as nonviable sexual subjects and their expressions of sexual attraction and desire coded as unnatural. In contrast, Black and other non-White women were more likely to be constructed as dangerously hypersexual, and their uptake of new sexual subjectivities was prohibited so as to protect them from unwanted male sexual attention or assault (Rice, 2014). However, the protection that privilege gave to White middle-class women taking up new sexual subjectivities also produced divisions amongst women, such as the idea that White women are problematically sexually promiscuous (see, for example, Espiritu, 2001).

In her analysis of the popularity of Paris Hilton in young Australian women's Myspace accounts, Dobson (2015) argued that Hilton was able to represent the ideals of postfeminism-consumerist, wealthy, able to 
constantly transform herself, and sexually agentic_-because she was White. In another cultural analysis, Butler (2013) argued that postfeminist media culture tends to "reinstate whiteness as the standard" (p. 48). Asking how this might be challenged, Butler argued that there were possibilities for "symbolic rupture" of the racial boundaries of postfeminism, for example, in the racial ambiguity, multiple identities, and explicit feminine masquerade of pop-music performer Nicki Minaj. But in her analysis of celebrity model Tyra Banks, Joseph (2009) highlighted the limits of symbolic rupture. Examining Banks's feminist and antiracist response to media coverage of her weight gain, Joseph noted how after briefly acknowledging its racist coverage of Banks, media coverage returned to a "postrace and postfeminist" standpoint that absented political analysis of racism in its representations of Black American women.

Such work introduced an important intersectional perspective underdeveloped in Gill's (2007) original paper. A concept developed from critical race studies, "intersectionality" highlights how gender is experienced differently at the intersections of other social categories, such as race, class, ethnicity, sexuality, and ability. (For discussion of intersectionality and feminist psychology, see Marecek, 2016.) Considering intersectionality, analysts of postfeminism showed how White, nondisabled, heterosexual, middle-class girls and young women were privileged in how they were represented in postfeminist media culture and in contrast to how diversely positioned women could take up, negotiate, resist, reject, or reappropriate subjectivities made available to them through postfeminist sensibility. This work was important for developing analysis of postfeminist sensibility 
because it showed how privilege is maintained within a discourse of individualism.

However, we note that in focusing on who is included, intersectionality-informed research on postfeminism has yet to develop other aspects more common in critical race studies. Such aspects include a more critical standpoint to the rhetoric of inclusion; analysis of resistance rather than access; attention to the unequal distribution of economic and social resources, as highlighted by anticapitalist, antiracist, and postcolonialist analyses; and a decentering of gender in the analysis so that gender is not assumed to be a fundamental organising principle, but mutually constituted at the intersections of other categorisations of race, class, sexuality, nation, ability, etc., that may take priority in a fluid way depending on the situation (Kim-Puri, 2005).

Despite these absences, research on new sexual subjectivities developed thinking about postfeminist sensibility in important ways. It expanded the reach of this work to include first person accounts as well as cultural analyses and showed possibilities and limitations in taking up new sexual subjectivities, including who could take these up, and in so doing highlighted the importance of an intersectional lens for analysis of postfeminist sensibility. This work paved the way for further developments in the study of postfeminist sensibility, which we discuss below.

\section{POSTFEMINISM REVISITED}

As a media culture, postfeminist sensibility developed alongside other shifts in gender relations, prompting further analysis in cultural and media studies, psychology, and other social sciences keen to explore a 
postfeminist influence on the meanings women (and to a lesser extent, men) use to make sense of themselves. This work has stimulated significant developments in how scholars think about representations of gender in both traditional and new media, and their implications for subjectivity. Reviewing the literature on postfeminist sensibility, we categorise these developments into four intersecting areas, these are analysis on postfeminist digital cultures; an expansion of the imperative to work on the body to include work on the mind; implications of new forms of feminist activism; and considerations of postfeminism as a transnational sensibility. Below, we discuss how each of these areas is shaping the analysis of postfeminist sensibility today.

\subsection{Digital transformations}

There is a surprising lack of discussion of online content and digital platforms in Gill's (2007) analysis of postfeminist sensibility. Addressing this gap, important developments in work on postfeminist sensibility have focused on the way particular constructs of ideal femininity and citizenship are produced online.

Cairns and Johnston (2015), for example, showed how online bloggers repositioned weight loss as the outcome of healthy, pleasurable eating, in contrast to weight loss produced from the unpleasant food restriction of diets. Such constructions incorporated feminist critiques of diets, while supporting the practice of diets (since the healthy eating that was promoted involved food restriction and monitoring of consumption). These accounts also created dispreferred subject positions of foolish dieter in contrast to happy and healthy food consumer, thus affirming postfeminist 
sensibility by locating women's empowerment in their body and consumer choices.

Other researchers explored the visibility afforded by vlog and blog digital technologies. For example, Dobson (2015) used postfeminist sensibility to contextualise young women's sexualised self-presentations on MySpace, arguing that despite a moral panic over such self-presentations, being able to video oneself provocatively pulling the zip down of tight shorts, for example, allowed these women to take up culturally valued subjectivities, as sexually savvy, desiring, and autonomous. Similarly, Riley and Evans (forthcoming) developed an analysis of fitness inspiration posts ("fitspo") on the microblogging site Tumblr. By conceptualising fitspo as a postfeminist sensibility, they were able to show the articulation of postfeminist themes in the posts, such as empowerment through work on the body and mind, and how these themes enabled such blogs to reproduce the thin ideal while critiquing dieting as unhealthy.

Such studies highlighted the importance of digital cultures as sites of postfeminist sensibility. They also developed thinking about postfeminist sensibility, identifying new contradictions within postfeminist sensibility, a more complex entanglement of individualist and community discourses than previously identified, and a representation of work on the self as hard or painful that was normally minimised in mainstream media make-over shows. These studies also highlighted the way the make-over paradigm had expanded to include an imperative to transform the mind as well as the body. 


\subsubsection{Psychologising of postfeminism}

Research focusing on the make-over paradigm identified the assumption that a transformation of one's outer appearance (through clothes, makeup, or cosmetic surgery) will produce a change in the psychological and emotional life of the person being transformed. BanetWeiser and Portwood-Stacer (2006), for example, showed how U.S. makeover shows constructed cosmetic surgery as the vehicle to psychological change, such as improved self-esteem. Similarly, Braun's (2007) analysis of media and surgeons' accounts of female genital cosmetic surgery showed how appearance concerns that affect sexual confidence were constructed as a psychological problem, solved with medical intervention. The logic of such accounts aligned with postfeminist sensibility and the prescription to work on the body but extended and blurred distinctions between the self and body, expanding attention to the psychological and emotional lives of women. This extension of the transformation imperative into the psychological is now evident across a range of media, including self-help literature that aligns itself with postfeminist sensibility by constructing work on the self as a requirement for optimal living (Riley, Evans \& Robson, forthcoming).

The move into psychology is also seen in recent media exhortations for women to love themselves and their bodies, to be confident, and to "awaken your incredible" (Banet-Weiser, 2015; Gill \& Elias, 2014). Such prescriptions for self-love and confidence represent a shift away from the previous decade's tone in women's media that derided women for having cellulite, deodorant marks, body hair, tan lines, etc. However, prescriptions for confidence and loving your body deepen expectations of self- 
improvement and self-transformation, while also constructing women as inherently flawed. Thus, an emerging feature of contemporary postfeminist sensibility is an understanding of femininity as psychologically pathological, managed through disciplined work on the mind and body, and in which "negative" emotions such as anger or anxiety are understood as the outcome of the flawed individual, and not a wider socio-political climate that damages women (Gill, 2011). Also see McRobbie (2009) for an earlier argument on illegible rage.

\subsubsection{Feminism returns}

Alongside an increased focus on psychology in postfeminist media have been highly public expressions of feminist activism. Examples of recent feminist activities are numerous, but include social media campaigns like EverydaySexism, \#YesAllWomen, and Hollaback; campaigns about objectifying media representations (e.g., Lose The Lads Mags, No More Page 3, and Feminist Frequency); activist movements such as the SlutWalks and FEMEN; and celebrity feminists (e.g., Emma Watson running UN backed HeForShe campaign, Beyonce's performance to a backdrop of "FEMINIST," and young celebrities such as Rowan Blanchard and Zendaya embracing feminist ideas). Feminist activism was reported on a global scale from America's Women's March following the election of Donald Trump to campaigns in Saudi Arabia for women to drive.

Feminist activism, it seemed, was popular again, in no small part because of the public displays and undeniable evidence of sexism and sexual violence that could not be explained away with postmodern irony. For example, in the U.S. Brock Turner case, a Stanford University student was caught raping an unconscious woman, the University attempted a 
cover-up, and when it went to court, the judge gave the rapist a light sentence so his "life wouldn't be ruined," after which, his father made a press statement that his son was being unfairly punished for "15 minutes of fun." Months later, the U.S. president-to-be was heard saying about women, "I just grab 'em by the pussy."

For some, the new visibility of feminist activism in response to such sexism casts doubt on the ongoing relevance of postfeminist sensibility as a construct, particularly as many media outlets shifted tone to also include explicit identification with feminism (e.g., Retallack, Ringrose, \& Lawrence, 2016). For example, Teen Vogue recently developed itself as a hotspot of "woke" writing for teens-a space for youth waking up to feminist ideas. However, these new articulations of feminism in the media and of feminist activism have characteristics of postfeminist sensibility. The Women's March, for example, included a range of women reappropriating the word "pussy" (e.g., knitting pink "pussy" hats to march in and carrying banners reading "Pussy strikes back") in ways that seemed to articulate a form of sexual subjectification (reclaiming/owning the word "pussy") that enabled them to object to objectification. There are also signs that media celebrations of feminism include a postfeminist twist that commercialises and individualises feminist activism. (See, for example, an advertisement in Elle magazine that described a T shirt with the slogan "we should all be feminists" as "office appropriate" when teamed with a $\$ 1600$ watch.) In this context, it seems appropriate to argue for the continued utility of postfeminist sensibility as a lens through which to think through at least some of the resurgence in feminist activism we are currently witnessing. 
We also see emerging new dynamics between feminist ideas in postfeminist media cultures. For example, the Glamour magazine video found at http://bit.ly/2x3LZGm uses female bonding and expertise to teach women to love their bodies and in the process come to enjoy wearing sexy lingerie. The video is affective (designed to move the viewer emotionally) and offers an implicit critique of the harm done to women living in a bodyjudgmental culture. Such media can be understood as both feminist in that they create a critique of body image culture as damaging to women, and postfeminist, since consumption, transformation, and sexual subjectivity are its end goals. Such media also have a global reach, much like feminist forms of digital activism (Baer, 2015), bringing us to our final theme of emerging research on postfeminist sensibility, that of transnational postfeminism.

\subsubsection{Transnational postfeminism}

One significant critique of earlier work on postfeminist sensibility was its focus on Anglo-American media content, such as textual analyses of Sex and the City or Bridget Jones' Diary. More recent research seeks to address this gap by documenting the transnational movement of postfeminist sensibility across a range of media, including Chinese "chick lit" and Russian self-help. Linked to the flows of global capital and geopolitics, particularly in relation to neoliberalism, these texts articulate key aspects of Gill's (2007a) elements of a postfeminist sensibility, but also link them to local values and practices, a process of "domestication" that produces complex, inconsistent, and contradictory yet systematic constructions of ideal femininity (Grzanka, Mann, \& Elliott, 2016). For example, Salmenniemi and Adamson's (2015) analysis of Russian self-help 
literature showed how several of the themes of postfeminist sensibility described by Gill (2007a, 2007c) (such as self-surveillance, the body as the locus of women's success, understanding that work on the self/body is empowering, and a reaffirmation of gender difference and biological essentialism) were tied into Russian cultural values of self-improvement and hard work, a historical communist rejection of feminism as a bourgeois ideology, and requirements for workers able to service new consumerist neoliberal economies.

Postfeminist sensibility has also been implicated in the way beauty work is linked to choice and empowerment across a range of global contexts. For example, Lazer (2017) argued that, in constructing makeup as "seriously girly fun!" (p. 53), magazine advertisements in Singapore represented a postfeminist sensibility, while Dosekun (2015) showed how a hyperfeminine appearance was embraced amongst young women in Lagos as a form of empowerment, although to maintain familial respectability, the young women did not engage with the hypersexual look associated with postfeminism in the Anglophone West. A similar shift away from sexual subjectification, and in this case, towards cuteness, was identified in Evans and Riley's (2017) analysis of online living doll movements in Ukraine that were inspired by Japanese Kawaii culture.

Analysis of different articulations of postfeminist sensibility across the globe suggests that postfeminist sensibility is "a versatile and pervasive cultural discourse [that] can travel through complex social terrains, deftly adapting to cultural, economic, and political shifts while maintaining its core characteristics" (Butler, 2013, p. 45). In seeing postfeminist sensibility as an object of study articulated in recurring but different patterns, academics are 
starting to make important connections between different representations and articulations of ideal femininity across what might otherwise be considered unconnected contexts. But the risk is that by simply providing evidence of different nations' variations of elements of postfeminist sensibility, we only reinstate the "otherness" of these accounts in contrast to their Western counterparts, and assume that the work is done. Drawing on Spivak's (1996, cited in Kim-Puri, 2005) description of the "transnational" as a world in which it is impossible for states and nations to escape the constraints of a neoliberal economic system, what is needed now is analysis of the complex interconnections, power asymmetries, and global flows of postfeminist sensibility. This also aligns with the more radical potential of intersectional research, which requires researchers to investigate and potentially revise White western feminist accounts of gender and patriarchy.

\section{CONCLUSION}

Postfeminist sensibility outlines a set of ideas about female subjectivity, embodiment, and empowerment. The ideas within postfeminist sensibility are not fixed but rather offer a flexible framework for considering how its different elements come together, in what contexts, and with what subjective effects. Its flexibility and thus failure to offer a coherent framework for analysis make it vulnerable to criticisms of being too ambiguous or so all-encompassing as not to be useful. But these flexibility, vagueness, and open-endedness are theoretically appropriate for poststructuralist informed work, which conceptualises subjectivity as produced through available discourses, discourses that in any culture are always multiple and contradictory. And, we argue, part of the success of 
postfeminist sensibility is its flexibility, allowing for research that spans a range of disciplines and contexts.

Despite some resurgence of feminist activism, we are not "over" postfeminism. $\frac{5}{}$ The set of ideas around ideal femininity that Gill termed "postfeminist sensibility" continues to circulate in and across media and everyday sense-making. How these ideas are taken up and their subjective effects are therefore an important direction for future research. Above, we have argued that postfeminist sensibility may be particularly useful for exploring gendered, racialised, and classed elements of neoliberalism evident in transnational postfeminism and digital cultures, as well as the psychologisation of the transformation imperative, and new forms of feminist activism. We conclude with the suggestion that such future research also needs a three-lens perspective that includes intersectionality, technology, and transdisciplinarity. Earlier, we made the case for the importance of an intersectional lens for the analysis of postfeminist sensibility, and how it might be further developed. Below, we develop our argument that future research needs to bring a focus on technology to the fore.

Postfeminist sensibility is mediated through a range of digital, social, and traditional media and through developments in physical technologies such as surgery, cosmetics, and other beauty practices. The mediating effect of technologies is integral to future analyses, for example, in the way social media platforms direct behaviours (e.g., to increase networks or

\footnotetext{
${ }^{5}$ See Ahmed (2012) and Grzanka et al. (2016) for a discussion of the rhetorical power that reduces sustained academic challenge of inequality and the status quo by calling something "over."
} 
share product information). Future research on postfeminism would also benefit from connecting with other critical concepts. For example, Lupton (2017) speaks of self-tracking apps as "postpanoptic" or "participatory surveillance," which might be used to develop analysis of the self-scrutiny aspect of postfeminist sensibility. Future research will also need to pay attention to the global reach of digital content.

Research on postfeminist sensibility is interdisciplinary, but in the main, researchers have read each other's work and applied it to inform research in their own discipline. As a somewhat interdisciplinary group of scholars ourselves, we see a direction for difficult but rewarding work in research that does not sit in a single discipline. Certainly, integration between first person and cultural analyses is central, but we could begin to ask a range of other transdisciplinary questions. For example, how might disability studies help psychologists and social scientists identify ways in which body normativity of postfeminism can be challenged? What would a geographical perspective, somewhat underrepresented in postfeminist sensibility research, add to research on transnational postfeminism? How might postfeminism inform the work of political science or health research? Through such questions, research on postfeminist sensibility may stake out new ground.

\section{ACKNOWLEDGEMENT}

We thank Rosalind Gill for comments on an earlier draft.

\section{REFERENCES}

Ahmed, S. (2012). On being included: Racism and institutional life. Durham, NC: Duke University Press. 
Baer, H. (2015). Redoing feminism: Digital activism, body politics, and neoliberalism. Feminist Media Studies, 16(1), 17- 34.

Banet-Weiser, S. (2015). 'Confidence you can carry!': Girls in crisis and the market for girls' empowerment organizations. Continuum Journal of Media \& Cultural Studies, 29(2), 182- 193.

Banet-Weiser, S., \& Portwood-Stacer, L. (2006). 'I just want to be me again!' Beauty pageants, reality television and postfeminism. Feminist Theory, 7(2), 255- 272.

Bay-Cheng, L. Y. (2015). The agency line: A neoliberal metric for appraising young women's sexuality. Sex Roles, 73, 279-291.

Braun, V. (2007). The women are doing it for themselves: The rhetoric of choice and agency around female genital 'cosmetic surgery'. Australian Feminist Studies, 24(60), 233- 249.

Butler, J. (1990). Gender trouble: Feminism and the subversion of identity. New York: Routledge.

Butler, J. (2013). For white girls only?: Postfeminism and the politics of inclusion. Feminist Formations, 25(1), 35- 58.

Cairns, K., \& Johnston, J. (2015). Choosing health: Embodied neoliberalism, postfeminism, and the 'do-diet'. Theory and Society, 44(2), 153- 175.

Diamond, L. M. (2005). I'm straight but I kissed a girl: The trouble with American media representations of female-female sexuality. Feminism and Psychology, 15(1), 104- 110.

Dobson, A. (2015). Postfeminist digital cultures: Femininity, social media and self representation. Basingstoke: Palgrave Macmillan.

Dosekun, S. (2015). For Western girls only? Post-feminism as transnational culture. Feminist Media Studies, 15(6), 960- 975.

Douglas, S. J. (2010). Enlightened sexism: The seductive message that feminism's work is done. New York: Times Books.

Duits, L., \& van Zoonen, L. (2007). Who's afraid of female agency? A rejoinder to Gill. European Journal of Women's Studies, 14(2), 161- 170.

Espiritu, Y. (2001). "We don't sleep around like White girls do": Family, culture, and gender in Filipina American lives. Signs: Journal of Women in Culture and Society, 26(2), 415- 440. 
Evans, A., \& Riley, S. (2013). Immaculate consumption: Negotiating the sex symbol in postfeminist celebrity culture. Journal of Gender Studies, 22(3), 268- 281.

Evans, A., \& Riley, S. (2014). Technologies of sexiness: Sex, identity, and consumer culture. New York: Oxford University Press.

Evans, A., \& Riley, S. (2017). The entrepreneurial practices of becoming a doll. In A. S. Elias, R. Gill, \& C. Scharff (Eds.), Aesthetic labour: Rethinking beauty politics in neoliberalism. London: Palgrave Macmillan.

Evans, A., Riley, S., \& Shankar, A. (2010). Technologies of sexiness:

Theorizing women's engagement in the sexualisation of culture. Feminism and Psychology, 20(1), 1- 18.

Flax, J. (1987). Postmodernism and gender relations in feminist theory. Signs: Journal of Women in Culture and Society, 12(4), 621-643.

Gavey, N. (2012). Beyond "empowerment"? Sexuality in a sexist world. Sex Roles, 66(11), 718- 724.

Gill, R. (2007a). Postfeminist media culture: Elements of a sensibility. European Journal of Cultural Studies, 10(2), 147- 166.

Gill, R. (2007b). Critical respect: The difficulties and dilemmas of agency and 'choice' for feminism: A reply to Duits and van Zoonen. European Journal of Women's Studies, 14(1), 69- 80.

Gill, R. (2007c). Gender and the media. Cambridge: Polity Press.

Gill, R. (2011). Sexism reloaded, or, it's time to get angry again! Feminist Media Studies, 11(1), 61- 71.

Gill, R. (2012). The sexualisation of culture? Social and Personality Psychology Compass, 6(7), 483- 498.

Gill, R. (2016). Post-postfeminism?: New feminist visibilities in postfeminist times. Feminist Media Studies, 16(4), 610-630.

Gill, R., \& Donague, N. (2013). As if postfeminism had come true: The turn to agency in cultural studies of 'sexualisation'. In S. Madhok, S.

Phillips, \& K. Wilson (Eds.), Gender, agency, and coercion (pp. 240-258). London: Palgrave Macmillan. 
Gill, R., \& Elias, A. S. (2014). 'Awaken your incredible': Love your body discourses and postfeminist contradictions. International Journal of Media and Cultural Politics, 10(2), 179- 188.

Griffin, C., Szmigin, I., Bengry-Howell, A., Hackley, C., \& Mistral, W. (2013). Inhabiting the contradictions: Hypersexual femininity and the culture of intoxication among young women in the UK. Feminism and Psychology, 23(2), 184- 206.

Grzanka, P. R., Mann, S., \& Elliott, S. (2016). The neoliberalism wars, or notes on the persistence of neoliberalism. Sexuality Research and Social Policy, 13(4), 297-307.

Hemmings, C. (2011). Why Stories Matter: The Political Grammar of Feminist Theory. Durham and London: Duke University Press.

Hollows, J. (2003). Feeling like a domestic Goddess: Postfeminism and cooking. European Journal of Cultural Studies, 6( 2), 179- 202.

Joseph, R. L. (2009). Tyra Banks is fat: Reading (post-)racism and (postfeminism in the new millennium. Critical Studies in Media

Communication, 26(3), 237- 254.

Kim-Puri, H. J. (2005). Conceptualizing gender-sexuality-statenation. Gender and Society, 19(2), 137- 159.

Lamb, S. (2010a). Feminist ideals of healthy female adolescent sexuality: A critique. Sex Roles, 62(5/6), 294- 306.

Lamb, S. (2010b). Porn as a pathway to empowerment? A response to Peterson's commentary. Sex Roles, 62(5/6), 314- 317.

Lamb, S., \& Peterson, Z. (2012). Adolescent girls' sexual empowerment: Two feminists explore the concepts. Sex Roles, 66(11-12), 703- 712.

Lazar, M. M. (2017). 'Seriously girly fun!': Recontextualising aesthetic labour as fun and play in cosmetics advertising. In A. S. Elias, R. Gill, \& C. Scharff (Eds.), Aesthetic labour: Rethinking beauty politics in neoliberalism. London: Palgrave.

Lupton, D. (2017). Digital Health: Critical and cross disciplinary perspectives. London: Routledge.

Marecek, J. (2016). Invited reflection: Intersectionality theory and feminist psychology. Psychology of Women Quarterly, 40(2), 177- 181. 
McRobbie, A. (2004). Postfeminism and popular culture. Feminist Media Studies, 4(3), 255- 264.

McRobbie, A. (2009). The aftermath of feminism: Gender, culture and social change. London: Sage.

Ong, A. (2006). Neoliberalism as exception: Mutations in citizenship and sovereignty. North Carolina: Duke University Press.

Peterson, Z. (2010). What is sexual empowerment? A multidimensional and process-oriented approach to adolescent girls' sexual empowerment. Sex Roles, 63(5-6), 307-313.

Retallack, H., Ringrose, J., \& Lawrence, E. (2016). 'Fuck your body image': Teen girls' Twitter and Instagram feminism in and around school. In Learning bodies (pp. 85- 103). Singapore: Springer.

Rice, C. (2014). Becoming women: The embodied self in image culture. Toronto: UT Press.

Rice, C., \& Watson, E. (2016). Girls and Sexting: The Missing Story of Sexual Subjectivity in a Sexualized and Digitally-Mediated World. In: J. Coffey, S. Budgeon, \& H. Cahill (Eds.) Learning Bodies. Perspectives on Children and Young People, vol 2. Singapore: Springer.

Riley, S., Evans, A., \& Robson, M. (forthcoming). Postfeminism and health. London: Routledge.

Ringrose, J., Harvey, L., Gill, R., \& Livingstone, S. (2013). Teen girls, sexual double standards and 'sexting': Gendered value in digital image exchange. Feminist Theory, 14(3), 305- 323.

Salmenniemi, S., \& Adamson, M. (2015). New heroines of labour: Domesticating post-feminism and neoliberal capitalism in Russia. Sociology, 49(1), 88- 105.

D. Sharma, \& F. Tygstrup (Eds.) (2015). Structures of feeling: Affectivity and the study of culture. Berlin: De Gruyter.

Stainton Rogers, W., \& Stainton Rogers, R. (2001). The psychology of gender and sexuality. Buckingham: Open University Press.

Tolman, D. L. (2012). Female Adolescents, Sexual Empowerment and Desire: A Missing Discourse of Gender Inequity. Sex Roles, 66(11012), 746- 757. 